\title{
Effect of Microclimate Alteration on Temperature Humidity Index (THI), Milk Production and Milk Composition in Jaffrabadi Buffaloes during Summer
}

\author{
B.D. Savaliya*, S.S. Parikh, R.B. Makwana, T.K. Patbandha, \\ P.M. Gamit and K.S. Murthy
}

Cattle Breeding Farm, Junagadh Agricultural University, Junagadh-362001, Gujarat, India

*Corresponding author

\section{A B S T R A C T}

\section{Keywords}

Temperaturehumidity index, Rectal temperature, Respiration rate, Milk yield, Fat percent

Article Info

Accepted:

12 March 2019

Available Online:

10 April 2019
In the current scenario, climate change is occurring all over the world and heat stress is increasing gradually. Heat stress can effectively reduce in buffaloes through evaporative cooling. Present experiment was carried out to find out the effect of fogger cooling on Temperature-Humidity Index (THI), physiological parameters, milk yield and milk composition in Jaffrabadi buffaloes during summer season at Cattle Breeding Farm, Junagadh Agricultural University, Junagadh, Gujarat (India) for a period of 9 weeks(from April to June, 2017). Thirty lactating Jaffrabadi buffaloes were divided in two groups of 15 each. Buffaloes of Group-I (control) were kept under loose housing without any cooling system, while buffaloes of Group II (experiment) were kept under loose housing with fogger cooling system operated from 11.00 a.m. to 4.00 p.m. Significantly $(P<0.05)$ lower THI value was observed in Group II buffalo shed. Though the difference was nonsignificant, lower rectal temperature and respiration rate were observed in the buffaloes of fogger group compared to control group. Milk yield and fat percent were increased significantly $(\mathrm{P}<0.05)$ in Jaffrabadi buffaloes of group II. Thus, it is concluded that the fogger cooling system was beneficial in terms of body comfort of the animals by reducing heat stress as well as increasing milk yield and fat percent in Jaffrabadi buffaloes during summer season.

\section{Introduction}

In the current scenario, climate change is occurring all over the world. Thermal stress is become a major limiting factor in livestock production under tropical climate during the summer season. Buffaloes are more prone to physical distress as they have poor heat tolerance due to scarcely distributed sweat glands and black body colour (Das et al.,
1999). The innate thermoregulatory mechanism in buffaloes is inadequate compared to cattle (Tharar et al., 1982). It is well known fact that adequate heat dissipation is essential for the maintenance of normal body temperature and normal functioning of the organs (Verma and Hussain, 1991). Heat stress leads to increased rectal temperature and subsequent decrease in feed and energy intake and the average effects on 
reproduction, milk production and composition (AI Said et al., 2000).

During summer, wetting of buffaloes can effectively reduce body temperature and respiration rate through cooling, which can achieved by wallowing, showering, sprinkling, mud plastering and some modern technologies like misters and foggers. Fogger cooling system was found beneficial in terms of the body comfort and the milk yield in Murrah buffaloes (Ambulkar et al., 2011). Foggers cooling system in summer was found beneficial in terms of body comfort as well as increasing the fat yield in Mehsana buffaloes (Jegoda et al., 2015). Fogger system consists of nozzles in a line placed 8-9 ft. above the floor. This system disperses very fine water droplets and cools the air in the barn and body surface. Scarce information is available on microclimate alteration by fogger cooling system on milk yield and body comfort in Jaffrabadi buffaloes during summer. Hence the investigation was undertaken to find out the exact effect of microclimate alteration to counteract the heat stress effect of summer.

\section{Materials and Methods}

The present study was conducted on thirty lactating Jaffrabadi buffaloes for the period of 9 weeks ( $8^{\text {th }}$ April to $15^{\text {th }}$ June, 2017) at Cattle Breeding Farm, Junagadh Agricultural University Junagadh. The buffaloes were divided into two groups fifteen each on the basis of body weight, daily milk yield and parity. Initial body weight of the buffaloes in group I and group II were $575.00 \pm 14.26 \mathrm{~kg}$ and $573.26 \pm 20.47 \mathrm{~kg}$, respectively. Buffaloes of group I were kept under loose housing without foggers (Control), while buffaloes of group II were kept under loose housing with foggers (experiment). This fogger system consisted of plastic fogger (NETAFIM brand) nozzles which were arranged in a line and placed 8 feet above the floor. The fogger cooling system was automatically controlled by an electronic timer and run for 3 minutes after an interval of every 2 minutes, operated daily during high atmospheric temperature hours in experimental shed from 11:00 to 16:00 hrs. Feeding requirements were calculated on the basis of average milk production and maintenance requirements as per ICAR (2010) feeding standards. Throughout the study period, animals were maintained under similar feeding and other farm managerial practices under loose housing system of management. Experimental animals were dewormed at regular interval and vaccinated against endemic diseases.

Milk production during morning and evening was recorded daily on electronic weighing machine. Weekly milk samples of $100 \mathrm{~g}$ from each buffalo were collected and analysed for fat, solid-not-fat, protein, lactose and ash content by using Ultrasonic Milk Analyzer (Lactoscan, Milkotronic Limited, Bulgariya).

Physiological responses viz. rectal temperature and respiration rate were measured weekly by clinical thermometer and the flank movements /minute, respectively, at 8:00, 11:00, 15:00 and 18:00 hrs to assess the body comfort. A Data Logger (HTC brand) was placed in the centre of the experimental shed at 8 feet height from the floor to record maximum and minimum temperature and relative humidity at one hour interval during whole experimental period to calculate Temperature-humidity index (THI).

\section{Statistical analysis}

Statistical analysis of experimental data was carried out by using two-sample ' $t$ ' test with equal variances as per the methods suggested by Snedecor and Cochran (1994)

Temperature-humidity index (THI) was calculated according to the equation reported by Ravagnolo et al., (2000): 
$\mathrm{THI}=(1.8 \times \mathrm{T}+32)-[(0.55-0.0055 \times \mathrm{RH})$ $\times(1.8 \times \mathrm{T}-26)]$

Where, T=air temperature $\left({ }^{\circ} \mathrm{C}\right)$ and $\mathrm{RH}=$ relative humidity $(\%)$

\section{Results and Discussion}

\section{Temperature Humidity Index (THI)}

Temperature-humidity index (THI) was used as an indicator of thermal comfort for dairy animals. The average THI values recorded in group I (control) and group II (experiment) were 84.42 and 78.66 respectively (Table 1 ). The peak THI value in group I and II were 85.75 and 80.48 respectively and was reached at $6^{\text {th }}$ week of the experiment during May2017 in both the experimental buffalo sheds. Significant $(\mathrm{P}<0.05)$ difference in the THI values was observed between the groups. Agarwal (2004) reported decreasing THI values from 84.1 to 82.78 in Murrah buffalo houses and Chanpongsang et al., (2010) revealed decreasing THI values from 81 to 77 in cattle houses due to mister cooling, supported the present results. Frazzi et al., (2000) reported dairy cattle barns equipped with fans and fans plus misting recorded temperatures of $31.5^{\circ} \mathrm{C}$ and $30.9^{\circ} \mathrm{C}$, respectively supporting the findings of effectiveness of evaporative cooling system in decreasing the temperature in cattle houses over air circulation by fans alone.

\section{Body temperature}

Lower body temperature $\left(99.58^{\circ} \mathrm{F}\right)$ was observed in Jaffrabadi buffaloes maintained under fogger cooling than the buffaloes maintained without any cooling system $\left(101.09^{\circ} \mathrm{F}\right)$ during peak hot hours (at 3:00 $\mathrm{pm})$. Though the difference was nonsignificant, fogger cooling had reduced body temperature of buffaloes by $1.5^{\circ} \mathrm{F}$ at the peak hot period suggesting that the fogger cooling was helpful in thermoregulation in Jaffrabadi buffalo.

Similar findings of decreased rectal temperature of $102.2^{\circ} \mathrm{F}$ was reported by Agarwal (2004) in dairy cows kept in houses equipped with mister cooling compared to without mister cooling system $\left(103.84^{\circ} \mathrm{C}\right)$. Rectal temperature values of $38.5^{\circ} \mathrm{C}$ and $39.3^{\circ} \mathrm{C}$ in cows (Boonsanit et al., 2010) and 38.7 and $39.4^{\circ} \mathrm{C}$ in crossbred cows (Chanpongsang et al., 2010) and $38.5 \pm 0.3^{\circ} \mathrm{C}$ and $39.3 \pm 0.3^{\circ} \mathrm{C}$ in dairy cattle (Siriwat et al., 2013) provided with and without supplemental cooling system, respectively, were consistent with the present results.

\section{Respiration rate}

The buffaloes in fogger cooling shed showed reduced respiration rate $(21.46)$ at $3: 00 \mathrm{pm}$ (peak hot hours) by 4.09 counts/minute as compared to that of control group (25.55). The difference was non-significant but lowered respiration rate in buffaloes under fogger shed might be due to decrease in heat stress due to cooling effect caused by provision of foggers. Decreased respiration rate due to provision of foggers reported in dairy cows (Correa-Calderon et al., 2002; Boonsanit et al., 2010) and buffaloes (Agarwal, 2004; Ambulkar et al., 2011) were in consistent with the present findings.

\section{Milk yield}

The average weekly milk yield of Jaffrabadi buffaloes maintained under fogger cooling was $50.33 \pm 1.36 \mathrm{~kg}$. This was significantly $(\mathrm{P}<0.05)$ higher as compared to the milk yield of the buffaloes maintained without any cooling devices $(44.81 \pm 1.58 \mathrm{~kg}$ ) (Table 2, Figure 1).

The buffaloes under fogger cooling system showed increased daily milk yield by 0.790 
$\mathrm{kg} /$ day/buffalo $(12.32 \%)$. It suggests that fogger cooling helped in reducing the heat stress and thereby augmented milk production significantly in Jaffrabadi buffaloes.

Table.1 Effect of fogger cooling on Temperature Humidity Index (THI) in Jaffrabadi Buffalo during summer

\begin{tabular}{|c|c|c|}
\hline \multirow{2}{*}{$\begin{array}{l}\text { Period } \\
\text { (Weeks) }\end{array}$} & \multicolumn{2}{|c|}{$\begin{array}{c}\text { Temperature-Humidity Index } \\
\text { (THI) }\end{array}$} \\
\cline { 2 - 3 } & $\begin{array}{c}\text { Group-I } \\
\text { (Control) }\end{array}$ & $\begin{array}{c}\text { Group-II } \\
\text { (Experiment) }\end{array}$ \\
\hline $\mathbf{1}^{\text {st }}$ & $82.96 \pm 0.31$ & $75.82 \pm 0.21$ \\
\hline $\mathbf{2}^{\text {nd }}$ & $82.34 \pm 0.31$ & $77.69 \pm .032$ \\
\hline $\mathbf{3}^{\text {rd }}$ & $83.15 \pm 0.36$ & $76.15 \pm 0.13$ \\
\hline $\mathbf{4}^{\text {th }}$ & $84.65 \pm 0.15$ & $79.73 \pm 0.41$ \\
\hline $\mathbf{5}^{\text {th }}$ & $85.21 \pm 0.29$ & $80.42 \pm 0.32$ \\
\hline $\mathbf{6}^{\text {th }}$ & $85.75 \pm 0.23$ & $80.48 \pm 0.24$ \\
\hline $\mathbf{7}^{\text {th }}$ & $85.53 \pm 0.24$ & $79.02 \pm 0.25$ \\
\hline $\mathbf{8}^{\text {th }}$ & $84.77 \pm 0.30$ & $78.12 \pm 0.31$ \\
\hline $\mathbf{9}^{\text {th }}$ & $85.46 \pm 0.12$ & $80.53 \pm 0.26$ \\
\hline $\mathbf{M e a n}^{\text {MeSE }}$ & $84.42 \pm 0.38^{\mathrm{a}}$ & $78.66 \pm 0.51^{\mathrm{b}}$ \\
\hline
\end{tabular}

Means bearing different superscript $(a, b)$ in a row differ significantly $(\mathrm{P}<0.05)$.

Table.2 Effect of fogger cooling on milk production in Jaffrabadi Buffalo during summer

\begin{tabular}{|c|c|c|}
\hline \multirow[t]{2}{*}{ Weeks } & \multicolumn{2}{|c|}{$\begin{array}{c}\text { Weekly milk } \\
\text { production/buffalo }(\mathrm{kg})\end{array}$} \\
\hline & Control & Experiment \\
\hline 1 & $51.59 \pm 4.91$ & $52.49 \pm 7.26$ \\
\hline 2 & $48.91 \pm 4.41$ & $54.60 \pm 6.03$ \\
\hline 3 & $48.23 \pm 4.33$ & $54.70 \pm 5.47$ \\
\hline 4 & $47.20 \pm 4.03$ & $53.20 \pm 5.25$ \\
\hline 5 & $45.70 \pm 3.98$ & $51.60 \pm 5.02$ \\
\hline 6 & $43.20 \pm 3.78$ & $49.40 \pm 5.13$ \\
\hline 7 & $41.97 \pm 3.73$ & $48.30 \pm 5.25$ \\
\hline 8 & $38.75 \pm 3.53$ & $45.40 \pm 5.12$ \\
\hline 9 & $37.70 \pm 3.37$ & $43.20 \pm 5.16$ \\
\hline Mean \pm SE & $44.81 \pm 1.58^{\mathrm{a}}$ & $50.33 \pm 1.36^{b}$ \\
\hline Daily Av. & $6.4 \pm 0.15$ & $7.19 \pm 0.21$ \\
\hline
\end{tabular}

Means bearing different superscript $(a, b)$ in a row differ significantly $(\mathrm{P}<0.05)$. 
Table.3 Weekly mean values of milk composition in Jaffrabadi buffalo

\begin{tabular}{|c|c|c|c|c|c|c|c|c|c|c|c|c|}
\hline \multirow[t]{2}{*}{ Week } & \multicolumn{6}{|c|}{ Control-Milk constituents (\%) } & \multicolumn{6}{|c|}{ Experiment - Milk constituents (\%) } \\
\hline & Fat & SNF & TS & Protein & Lactose & Ash & Fat & SNF & TS & Protein & Lactose & Ash \\
\hline 1 & 8.15 & 11.45 & 19.90 & 4.30 & 6.44 & 0.96 & 8.15 & 11.89 & 20.04 & 4.18 & 6.40 & 0.97 \\
\hline 2 & 8.15 & 11.65 & 19.87 & 43 & 6.49 & 0.98 & 8.32 & 11.80 & 20.13 & 4.75 & .24 & 0.99 \\
\hline 3 & 8.13 & 11.85 & 19.85 & 4.26 & 6.44 & 0.99 & 8.43 & 11.82 & 20.23 & 5.07 & 72 & 0.98 \\
\hline 4 & 8.17 & 11.76 & 19.89 & 4.42 & 6.56 & 0.97 & 8.51 & 11.70 & 20.22 & 4.39 & .46 & 0.97 \\
\hline 5 & 8.12 & 11.79 & 19.84 & 4.24 & 6.78 & 0.98 & 8.61 & 11.67 & 20.28 & 31 & 6.58 & 0.96 \\
\hline 6 & 8.14 & 11.68 & 19.86 & 4.37 & 6.32 & 0.94 & 8.47 & 11.71 & 19.98 & 4.11 & 0.16 & 0.97 \\
\hline 7 & 8.11 & 11.96 & 20.08 & 4.39 & 6.54 & 1.01 & 8.70 & 11.67 & 20.37 & 4.42 & 5.99 & 1.02 \\
\hline 8 & 8.15 & 11.72 & 19.87 & 4.29 & 6.21 & 0.95 & 8.68 & 11.61 & 20.28 & 4.45 & 6.85 & 0.98 \\
\hline 9 & 8.18 & 11.94 & 20.14 & 4.38 & 6.28 & 1.01 & 8.69 & 11.75 & 20.37 & 4.33 & 6.75 & 0.97 \\
\hline Mean & $8.15^{\mathrm{a}}$ & 11.78 & 19.92 & 4.30 & 6.47 & 0.98 & $8.51^{b}$ & 11.72 & 20.21 & 4.31 & 6.28 & 0.99 \\
\hline SE & 0.007 & 0.035 & 0.036 & 0.018 & 0.015 & 0.007 & 0.063 & 0.028 & 0.046 & 0.002 & 0.075 & $\mathbf{0 . 0 0 9}$ \\
\hline
\end{tabular}

Means bearing different superscript $(a, b)$ in a row differ significantly

Significant $(\mathrm{P}<0.05)$

Fig.1 Effect of fogger cooling on milk production in Jaffrabadi Buffalo during summer

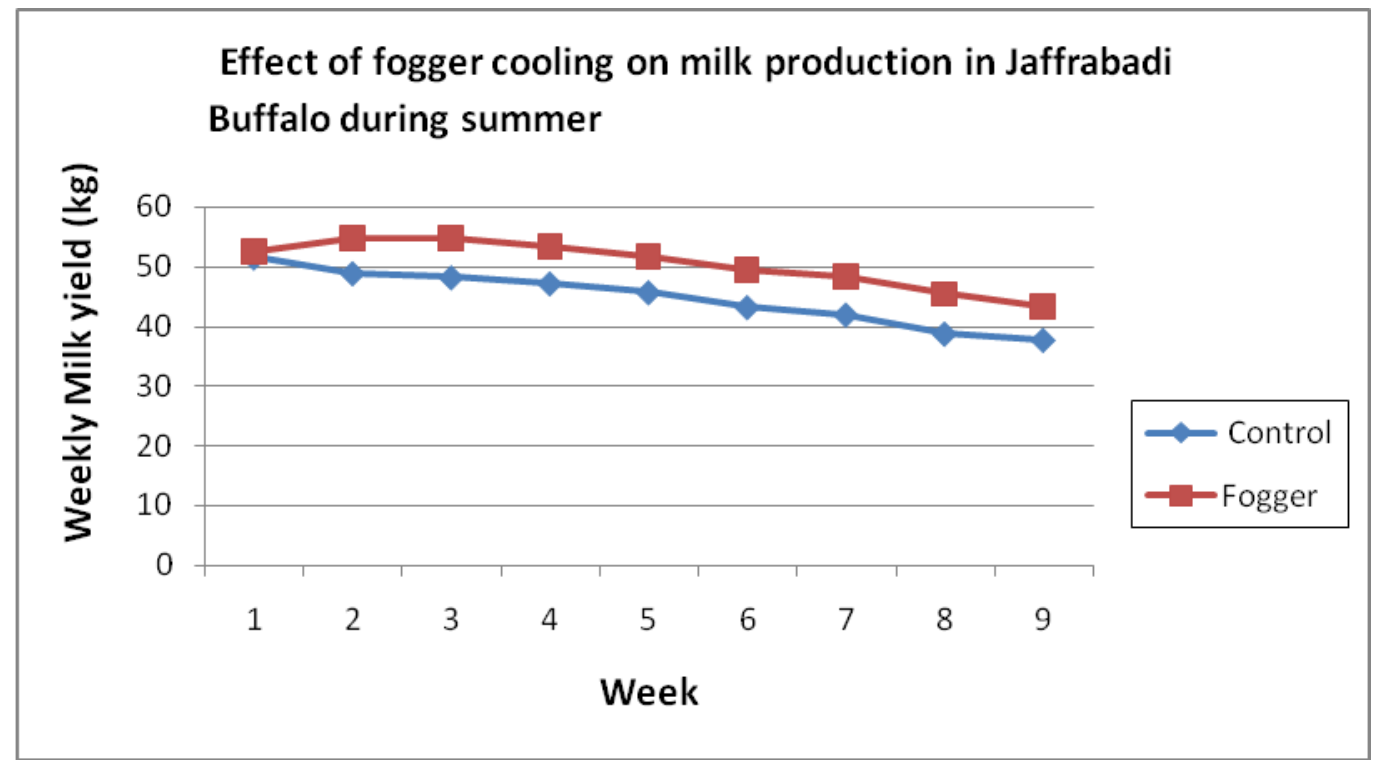

\section{Milk composition}

Weekly overall mean values of milk fat percent was significantly $(\mathrm{P}<0.05)$ higher $(8.51 \pm 0.06)(4.4 \%)$ in experiment group of Jaffrabadi buffaloes as compared to control group of buffaloes $(8.15 \pm 0.01)$. Other milk constituent viz. SNF, TS, Protein, lactose and ash did not differ significantly (Table 3 ).
Agarwal (2004) reported that the milk production in Murrah buffaloes was 7.58 and 8.60 in control (allowed for wallowing) and mister system, respectively. Similarly, milk production of $16.9 \pm 1.9$ and $12.6 \pm 0.6 \mathrm{~kg} /$ day were reported by Chanpongsang et al., (2010) in crossbred primiparous cows housed under evaporative cooling housing system and open 
housing system. Milk yield of $5.63 \mathrm{~kg}$ and $5.32 \mathrm{~kg}$ in Murrah buffalo maintained under the high-pressure fogger system and control, respectively, were reported by Ambulkar et al., (2011) which corroborate with the present findings.

In conclusion, the result showed that fogger cooling in the buffalo shed reduced heat stress due to evaporating cooling effect of water. Milk yield and fat percent were increased significantly in Jaffrabadi buffaloes during hot summer season. Physiological and environmental parameters viz. rectal temperature, respiration rate and THI value were lowered in buffaloes under fogger shed by $1.51^{\circ} \mathrm{F}, 4.09$ counts/minute and $5.76 \mathrm{THI}$, respectively, during peak hot hours in summer. Therefore, it is concluded that the fogger cooling system was beneficial in terms of body comfort of the animals as well as increasing milk yield and fat percent in Jaffrabadi buffaloes during summer season.

\section{References}

Agarwal, A. 2004.Effect of environment on hormones, blood metabolites, milk production and composition under two sets of management in cows and buffaloes. $\mathrm{PhD}$ thesis submitted to National Dairy Research Institute, Karnal (Haryana), India.

Al Saied, A.M., Habeeb, M.K.I., Yousef, H.M. 2000.Blood and milk contents of Triiodothyromine (T3) and cortisol in lactating buffaloes and change in milk yield and composition as a function of lactation number and ambient temperature. Arab $J$ Nuclear SciApplic.33 (2): 313-322

Ambulkar, D.R., Nikam, S.D.,Barmase,B.S., Ali, S.Z and Jirapure, S.G. 2011.Effect of a high-pressure fogger system on body comfort and milk yield in Murrah buffaloes during the summer.
Buffalo bulletin.30 (2):130-38.

Boonsanit, D., Chanpongsang, S. and Chaiyabutr, N. 2010.Effects of supplemental recombinant bovine somatotropin (rbST) and cooling with misters and fans on renal function in relation to regulation of body fluids in different stages of lactation in crossbred Holstein cattle. AsianAustralian Journal of Animal Science.23:355-365.

Chanpongsang, S., Choktananukul, V., Jamikorn, U., Chaiyabutr, N. and Suadsong, S. 2010. Effects of Evaporative Cooling System on Productive and Reproductive Performance and some Physiological Parameters of Crossbred Holstein Friesian Cattle in Tropical Conditions, Sustainable Improvement of Animal Production and Health. Food and Agriculture Organization of the United Nations, Rome, pp: 105-110.

Correa-Calderon, A., Avendano-Reyes, L., Rubio-Villanueva, A., Armstrong, D.V., Smith, J.F. and DeNise, S.K. 2002.Effect of a cooling system on productivity of Holstein cows under heat stress. Agrociencia (Montecillo) 36: 531.

Das, S.K., Upadhyaya, R.C. andMadan, M.L. 1999. Heat stress in Murrah buffalo calves. Livest Prod Sci., 61(1):71-78

Frazzi, E., Calamari, L., Calegari, F. and Stefanini, L. 2000.Behavior of dairy cows with different barn cooling systems. Transactions ASAE.43:387394.

ICAR, 2010. Nutrient Requirement of cattle and buffalo. Third revised edition. Indian Council of Agricultural Research, KrishiBhavan, New Delhi, India.

Jegoda, M.N., Patel, J.B., Prajapati, K.B. and Ankuya, K.J. 2015.Effect of foggers on production performance and feed 
intake of Mehsana buffaloes in summer. Indian J. Dairy Sci., 68(4):376-378.

Ravagnolo, O., Misztal, I. and Hoogenboom, G. 2000. Genetic component of heat stress in dairy cattle, development of heat index function. J. Dairy Sci., 83:2120-2125.

Siriwat, S., Thuchadaporn, C. and Junpen, S. 2013. Effect of Improved Cooling on Daily Rhythmicity of Body Temperature in Cross-bred Holstein Dairy Cows under Tropical Conditions. Thailand Journal of Veterinary Medicine. 43(3): 367-373.
Snedecor, G.W. and Cohran, W.G. 1994.Statistical Methods. $8^{\text {th }}$ ed. Affiliated East West Press Pvt. Ltd., New Delhi, India.

Thahar, A., Moran J.B., Seripto. 1982. Observation on the Hair and Skin of Indonesian Cattle and Buffalo and Their Relationship to Heat Tolerance. SABRAO Journal. 14(2): 152-157

Verma, D.N. and Hussain, K.Q.1991. Effect of shower on physiological parameters, nutrient utilization and milk production in buffaloes. Animal Breeding Abst., 59(2): 133.

\section{How to cite this article:}

Savaliya, B.D., S.S. Parikh, R.B. Makwana, T.K. Patbandha, P.M. Gamit and Murthy, K.S. 2019. Effect of Microclimate Alteration on Temperature Humidity Index (THI), Milk Production and Milk Composition in Jaffrabadi Buffaloes during Summer. Int.J.Curr.Microbiol.App.Sci. 8(04): 1379-1385. doi: https://doi.org/10.20546/ijcmas.2019.804.160 